\title{
The Process of Students' Mathematical Connection in Solving Mathematical Problems in terms of Learning Styles
}

\author{
Baiduri Baiduria $^{\text {, }}$ Arif Hidayatul Khusnab ${ }^{\mathrm{b}}$, and Mar'atus Solikhah ${ }^{\mathrm{c}}$ \\ aUniversity of Muhammadiyah Malang, Indonesia (ORCID: 0000-0002-4323-6107) \\ bUniversity of Muhammadiyah Malang, Indonesia (ORCID: 0000-0002-8107-4591) \\ 'University of Muhammadiyah Malang, Indonesia (ORCID: 0000-0003-1739-2963)
}

Article History: Received: 10 November 2020; Revised 12 January 2021; Accepted: 27 January 2021; Published online: 5 April 2021

\begin{abstract}
The purpose of this study was to describe the process of students' mathematical connections in solving mathematical problems in terms of learning styles. The type of research used is descriptive research with a qualitative approach. The research subjects were six students consisting of two students who have a visual learning style, two students who have an auditory learning style, and two students who have a kinesthetic learning style. Student learning style data were collected through learning style questionnaires, while student connection process data were collected through mathematical connection test sheets and interviews. Data credibility is done by triangulating sources and methods. Data from the six subjects consisting of two students for each of these learning styles were described and categorized from the same, different, and specific views. The subjects obtained from the results of the learning style questionnaire were compared using the results of the mathematical connection test and interviews. Data analysis was guided by four steps to solve Polya's problems and was carried out in three stages, namely data condensation, data presentation, and conclusions. The results showed that there are differences in the mathematical connection process carried out by students who have visual, auditory, and kinesthetic learning styles in the step of understanding the problem. However, there are similarities in the mathematical connection process carried out by students who have visual and kinesthetic learning styles at the step of compiling a completion plan and checking again. while students who have a different auditory learning style from students who have visual and kinesthetic learning styles in implementing the completion plan and rechecking. The process of mathematical connection of students who have an auditory learning style at the step of checking back cannot be seen, because these students do not take this step when solving problems. Researchers suggest that teachers need to accustom students to connecting mathematics both internally and externally and pay attention to the emphasis of the material given to students so that students' mathematical connections are more developed. because the student did not take this step when solving the problem. Researchers suggest that teachers need to accustom students to connecting mathematics both internally and externally and pay attention to the emphasis of the material given to students so that students' mathematical connections are more developed. because the student did not take this step when solving the problem. Researchers suggest that teachers need to accustom students to connecting mathematics both internally and externally and pay attention to the emphasis of the material given to students so that students' mathematical connections are more developed.
\end{abstract}

Keywords: mathematical connections, problem solving, learning style

\section{Introduction}

Mathematical connections are very important for students, especially in learning mathematics, because it makes students understand that mathematics is a science that can relate to other disciplines such as science, economics, social, culture, and so on, and relates to

\section{Corresponding Author: Baiduri Baiduri $\mathbb{1}$ e email: baiduri@umm.ac.id}

Citation Information: Baiduri, B., Khusna, A. H., \& Solikhah, M. (2021). The Process of Students' Mathematical Connection in Solving Mathematical Problems in terms of Learning Styles. Turkish Journal of Computer and Mathematics Education, 00(0), 000-000. 
problems in everyday life (Romli, 2016). The mathematical connection acts as a basis for thinking mathematically for students, so that students are able to connect the relationships concepts that have been obtained for use in real contexts (Latipah \& Afriansyah, 2018; Sari, Sudirman, \& Chandra, 2018). Based on the research results, the level of mathematical connection of students in Indonesia is in the low category (Anita, 2014; Apriyono, 2018; Diana et al., 2017; Fauzi \& Priatna, 2019; Kenedi et al., 2019; Latipah \& Afriansyah, 2018; Rismawati et al., 2017; Sari et al., 2018; Tasni \& Susanti, 2017). The students' low level of mathematical connection is seen from the unfulfilled three indicators of mathematical connections, namely identifying the relationship of mathematical ideas, understanding that mathematical ideas are connected to produce a complete whole, and representing mathematical ideas in contexts inside or outside mathematics (Anita, 2014; Apriyono, 2018; Hendriana, Slamet, \& Sumarmo, 2014; Rismawati et al., 2017). The low ability of mathematical connections in solving problems is influenced by gender, anxiety, self-confidence, and how to solve problems (Aini et al., 2016; Anita, 2014; Apriyono, 2018; Diana et al., 2017; Fauzi \& Priatna, 2019; Hendriana et al., 2014; Kenedi et al., 2019; Lee \& Kung, 2018; Mazana et al., 2018; Mhlolo, 2012; Puteh \& Khalin, 2016; Rismawati et al., 2017; Romli, 2016).

Mathematical connection refers to the ability to connect mathematical facts, concepts, principles, operations and procedures both internally and externally, so as to solve problems (Hidayah, Kurniaasih, \& Rohmad, 2019; Latipah \& Afriansyah, 2018). Internally, the ability of mathematical connections is seen as the ability to connect mathematical concepts, while externally, the ability of mathematical connections is seen as the ability to connect mathematics with other disciplines or everyday life (NCTM, 2000; Siagian, 2016). The object of study in mathematics consists of facts, concepts, operations, principles and procedures (Apriyono, 2018; Fauzi \& Priatna, 2019). The process of mathematical connection is a process of thinking in identifying and connecting mathematical ideas (internally), and connecting mathematics with other disciplines or daily life (externally) (Diana et al., 2017; Poladian \& Zheng, 2016). This research focuses on the connection between ideas in mathematics and mathematical connections in everyday life. The connection between ideas in mathematics consists of three aspects, namely identifying the relationship between facts, concepts, and mathematical principles on the problem to be solved, using the relationship between facts, concepts, mathematical principles to create models or formulas needed to solve problems, and making relationships between one concept with another in solving problems (Aini et al., 2016; Apriyono, 2018; Romli, 2016; Sari et al., 2018). The two components in the mathematical connection are used as indicators of a mathematical connection. The researcher intends to focus on these two components in the hope that the researcher is better able to reveal thoroughly related students' mathematical connection activities.

The problem solving used in this study is in accordance with the Polya stages. According to Polya (1973), problem solving in mathematics consists of four main steps, namely understanding the problem, compiling a plan, implementing a plan, and checking again. Polya's steps are used in this study because each Polya's problem solving activity is systematic and simple, making it easier for students to solve problems. Solving problems is one way to be able to see and build students' mathematical connections (Ariati \& Hartati, 2017; Hadi \& Radiyatul, 2014). Students can use all known information and relate the information to obtain relevant answers (Tasni \& Susanti, 2017). Through the connection process, students can translate questions into a mathematical form and connect mathematical concepts and procedures (Sari et al., 2018). Based on Polya's four steps, understanding, aspects, and indicators of mathematical connections, the researcher prepared indicators for the mathematical connection process of students in solving mathematical problems which consisted of four stages, namely understanding the problem (writing down known information on the problem by translating it 
into mathematical language and writing what which is asked in the problem by presenting the problem addressed to the problem), compiling a solution plan (identifying the known and questioned information relationships with facts, concepts, and mathematical principles, using the relationship of facts, concepts and principles to write the mathematical model or formula needed in solve problems, and suggest mathematical operations and procedures that will be used to solve problems) (Aini et al., 2016; Diana et al., 2017; Romli, 2016; Sari et al., 2018).

Each student has a different way of thinking and creativity in observing, processing, and processing information to solve problems (Ariati \& Hartati, 2017; Maftuh, 2018; Sundayana, 2016). The way a person observes, processes, and processes information to solve a problem through a different perspective is called a learning style (Argarini, 2018; Ghufron \& Risnawita, 2012; Suparman, 2010; Zulyanty et al., 2017). There are three types of learning styles, namely visual learning styles, auditory learning styles, and kinesthetic learning styles (DePorter \& Hernacki, 2013). Visual learning style is a type of learning style that relies on the ability of the visual senses to seek and process information. Auditory learning style is a type of learning style that relies on the sense of hearing to seek information and process information. Kinesthetic learning styles are types of learning styles that rely on physical involvement such as touch or movement. Learning styles are one of the factors that differentiate the way students solve problems (Argarini, 2018; Budiarti \& Jabar, 2016; Maftuh, 2018; Sundayana, 2016; Zulyanty et al., 2017). Differences in learning styles will affect the way the problem is solved, that is, each visual, audio, and kinesthetic learning style has differences in the problem solving process (Richardo et al., 2014). The difference in how to solve problems from students who have these three learning styles is also used as a reference to see the effect of mathematical connection abilities on student achievement, so in this case, learning styles become one of the internal factors of students' mathematical connections (Apipah \& Kartono, 2017; Dwirahayu \& Firdausi, 2016; Wiguna et al., 2019).

Some of the previous research on the connection of mathematics in elementary/junior high school (Hidayati et al., 2020; Kenedi et al., 2019) and high school was based on the ability of mathematics and gender in solving math problems (Baiduri et al., 2020). The mathematical connection skills of grade VIII junior high school students in algebra and geometry in terms of student gender, namely male and female students (Apriyono, 2018). The difference between this study and this research is that in this study, the selection of subjects from male and female gender is based on equal ability levels seen from the math ability test and report card scores, whereas in this study the subject selection from three learning styles was based on the results of the student learning style questionnaire. Another research is about the effect of mathematics anxiety on the mathematical connection ability of junior high school students (Anita, 2014). The study shows that math anxiety has a negative effect on mathematical connection abilities. The difference between this study and this research is that in this study, the research approach used is quantitative with data processing using the multiple regression-correlation method of the mathematics anxiety questionnaire and the mathematical connection ability test in the form of description questions, whereas in this study the research approach used was qualitative with triangulation of methods and sources. Other research, namely the connection of mathematics and self-confidence, shows that contextual learning with manipulative mathematics is better at improving students' mathematical connection skills, so there is a moderate correlation between mathematical connections and self-confidence (Hendriana et al., 2014). The difference between this research and this research is that the research was in the form of a quasi-experimental study with a pre-test post-test control group design involving 67 ninth grade students, while this study was a descriptive qualitative study, using triangulation of sources and methods for data credibility involving 2 subjects from each of the three categories of learning styles. As for 
previous research that links the connection with problem solving. Research on the mathematical connection process of students with high and low abilities in solving flat shape problems, which shows that students with high mathematical abilities have a more complete mathematical connection process in problem-solving steps than students with low math abilities who do not take the look back step (Aini et al., 2016). The difference between this study and this research is that the subject taking in the study was carried out by means of a preliminary test, whereas in this study, the subject taking was carried out using a learning style questionnaire. Another research is about the mathematical connection process of junior high school students in solving story problems, which shows that the mathematical connection process of students is shown by the ability to translate questions into mathematical form and the ability to connect mathematical concepts and procedures (Sari et al., 2018). The difference between this research and this research is that the research is a case study type by selecting one student who has a unique completion process as the subject and the connection test sheet related to the application of algebra, whereas in this study, two subjects were selected from each of the three categories of learning styles and The connection test sheet deals with the area of the trapezoid and the triangle and the perimeter of the rectangles. Other research on the mathematical connection process of students with reflective cognitive style in solving algebraic problems based on the SOLO taxonomy, which shows that students with reflective cognitive types have a range from rational to abstract expansion of the connection process in the SOLO taxonomy (Diana et al., 2017). The difference between this study and this research is that the research subjects are three subjects from one category, namely the reflective cognitive style, whereas in this study, two subjects came from each of the three categories of learning styles. Thus, this study focuses more on the mathematical connection process carried out by students who have visual, auditory, and kinesthetic learning styles in solving mathematical problems, therefore, the purpose of this study is to describe the process of students' mathematical connections in solving mathematical problems. in terms of three learning styles, namely visual learning styles, auditory learning styles, and kinesthetic learning styles.

\section{Method}

\subsection{Types and Research Approaches}

The type of research used is descriptive. It is descriptive with a qualitative approach, because it is based on the research objectives, namely to describe the process of students' mathematical connections in solving mathematical problems in terms of learning styles. The approach used in this study is a qualitative approach. A qualitative approach is an approach that leads to a detailed description of events, activities, beliefs, problems, and individual or group understanding of something, resulting in generalizations (Anggito \& Setiawan, 2018).

\subsection{Research Subjects}

The subjects of this study were six students from class VIII, totaling 21 students. The research subject was taken based on three student learning styles, consisting of two visual learning style students, two auditory learning style students, and two kinesthetic learning style students. Subjects totaling six students aim to obtain more in-depth data about the process of students' mathematical connections in solving math problems based on learning styles.

\subsection{Data Collection}

The data needed in this study were obtained by using three data collection techniques, namely questionnaires, tests, and interviews. The questionnaire used in this study was a learning style questionnaire, with the aim of obtaining data about the learning styles possessed by students so that with this data the researcher could determine the research subject. The test 
conducted by the researcher aims to determine the process of students' mathematical connection in solving math problems in terms of student learning styles. The test given to students is in the form of description questions that aim to find out the students' answers in writing and are given after determining the subject. The interview used by the researcher was a free guided interview with sub questions related to the mathematical connection test (Arikunto, 2014). This interview aims to strengthen information about the student's mathematical connection process from the results of students' mathematical connection tests.

\subsection{Data Credibility}

The credibility of the data in this study was carried out through triangulation of sources and methods (Denzin \& Yvonna, 2009; Sugiyono, 2015). Triangulation of sources in this study was carried out by examining the data obtained through the source, namely two students from each of the three learning styles, namely two students who had a visual learning style, two students who had an auditory learning style, and two students who had a learning style. kinesthetic. Data from two students from each of these learning styles were described and categorized from the same, different, and specific views. Method triangulation in this study was conducted by comparing the data obtained, namely two students from each of the three learning styles as subjects obtained from the learning style questionnaire results compared using the results of the mathematical connection test and interviews.

\subsection{Instruments}

There are three instruments used to collect data in this study, namely a learning style questionnaire, a mathematical connection test sheet, and an interview guide. The type of learning style questionnaire used is a closed questionnaire consisting of 42 statements with five answer choices (Budiarti \& Jabar, 2016; Maftuh, 2018; Sundayana, 2016). The reason the researcher adapted the questionnaire from the study was because the number of items was sufficient to collect data and the language used in the statement was easier to understand. The test sheet is a mathematical connection question in the form of a description of the area of the trapezoid and the triangle and the perimeter of the rectangle. Researchers develop mathematical connection test questions that refer to the 2014 PISA (Program for International Student Assessment) model questions (Kogure, 2013). The reason the researcher made the test questions by referring to the PISA model questions was because these questions required students to use their connection skills to solve math problems. Researchers used interview guidelines as a reference for conducting interviews to determine the process of students' mathematical connections in solving mathematical problems.

\subsection{Data Analysis}

Data analysis used in this research is data condensation, data presentation, and conclusion drawing (Sugiyono, 2015). Data condensation in this study refers to the process of selecting important things from the data, summarizing, and removing unnecessary ones. The presentation of the data uses narrative text obtained from the test results referring to Polya's four problem solving steps and the results of interviews to describe each of the mathematical connection processes of students who have visual, auditory, and kinesthetic learning styles in solving math problems. Drawing conclusions is the final stage of all the data that has been obtained and data analysis activities as a result of the research. Conclusion in this study aims to describe the process of students' mathematical connections in solving given mathematical problems in terms of student learning styles (Aini et al., 2016; Diana et al., 2017; Romli, 2016; Sari et al., 2018) in table 1. 
Table 1. Indicators of Students' Mathematical Connection Process in Solving Mathematics Problems According to their Polya's Steps

\begin{tabular}{ll}
\hline \multicolumn{1}{c}{ Polya's steps } & \multicolumn{1}{c}{ Mathematical Connection Process } \\
\hline Understanding the problem & $\begin{array}{l}\text { Write down the known information on the problem in } \\
\text { mathematical language } \\
\text { Write down what is asked in the question by stating the } \\
\text { problem addressed in the question }\end{array}$ \\
\hline Devising a completion plan & $\begin{array}{l}\text { Identify known and questioned information relationships } \\
\text { with mathematical facts, concepts, and principles } \\
\text { Using relationships of facts, concepts and principles to write } \\
\text { mathematical models or formulas needed to solve problems } \\
\text { Prescribes the operations and mathematical procedures that } \\
\text { will be used to solve the problem }\end{array}$ \\
\hline Carry out the completion plan & $\begin{array}{l}\text { Making connections between concepts and procedures for } \\
\text { solving problems }\end{array}$ \\
Apply the relationship between concepts and procedures and \\
mathematical operations to solve problems \\
Using procedures by performing arithmetic operations \\
according to the planned strategy \\
\hline Re-checking the suitability of facts, concepts, principles, \\
operations, and procedures used in solving problems \\
Re-check the accuracy of the procedure or steps used \\
Re-check the accuracy of the calculation results obtained
\end{tabular}

\section{Findings}

As explained in the introduction, the purpose of this study is to describe the process of students' mathematical connections in solving mathematical problems in terms of three learning styles, namely visual learning styles, auditory learning styles, and kinesthetic learning styles.

\subsection{The Process of Mathematical Connections of Students Who Have Visual Learning Styles in Solving Problems}

The process of mathematical connection of students in understanding the problem is to write down the information that is known from the question in the form of a parallelogram image along with the information related to the problem in the question, namely the area of land for oranges and banana land. The connections that students make in the step of understanding the problem lead to connections between ideas in mathematics. In Figure 1, it can be seen that in understanding the problem, students write down the information that is known to the problem in the form of a parallelogram picture along with the length of each side of the parallelogram, as well as a picture of the position of the bounding line and the length.

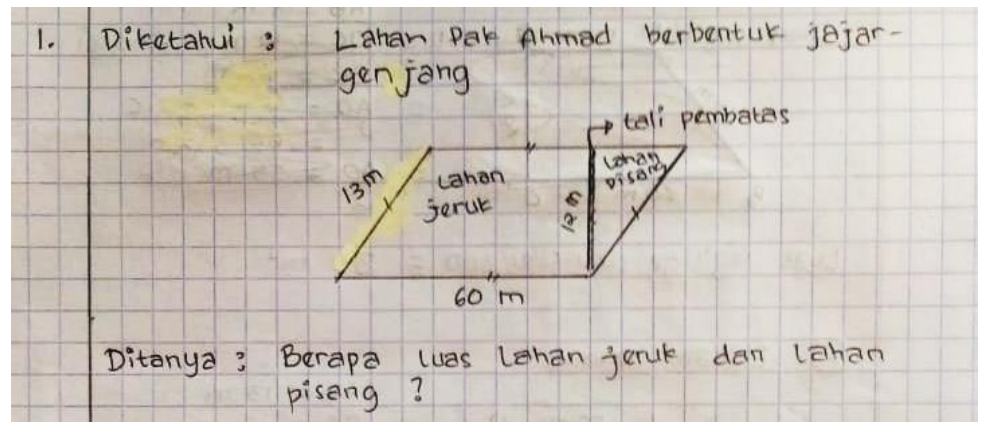

Figure 1. The mathematical connection process of students who have a visual learning style in understanding problems 
The results of the following interview also show that in understanding the problem, students write down the information that is known to the question in the form of a parallelogram picture along with the length of each side of the parallelogram, as well as a picture of the position of the bounding line and its length. Students also raised the problems that were asked in the questions, namely the area of land for oranges and land for bananas.

$\mathrm{P}$ : Tell me how you understand the problem from the question?

$\mathrm{V}$ : After I read the problem, I drew Pak Ahmad's land shape which was like a parallelogram and the position of the bounding rope, then I wrote the length of the land side and the length of the bounding rope with each side length of $60 \mathrm{~m}$ and $13 \mathrm{~m}$, and the length of the bounding line of $12 \mathrm{~m}$. Then I wrote down what was asked in the questions.

$\mathrm{P}$ : Try to state what is asked from the question?

$\mathrm{V}$ : Asking about the area of land for oranges and the area of banana land, Bu.

The process of mathematical connection of students in preparing a settlement plan is by using the Pythagorean formula to first find the length of the base of the right triangle. The connections made in the planning step lead to connections between ideas in mathematics. The process of connecting students in carrying out the settlement plan is by using the triangle area formula to calculate the area of the banana land and the trapezoid formula to calculate the area of land for oranges. The connections made in the step of executing the plan of completion are connections between ideas in mathematics and mathematical connections in everyday life. The mathematical connection process of students who have a visual learning style in checking again is by checking the suitability between the results of the answers from the pictures, the formulas used, and the results of the calculations obtained. The connections made by students who have a visual learning style at the reexamination step lead to connections between ideas in mathematics and mathematical connections in everyday life. The connection between ideas in mathematics can be seen from the use of relationships between facts, concepts, mathematical principles to create models or formulas needed to solve problems. The connection of mathematics in everyday life can be seen from the application of the relationship between concepts and procedures and operations of mathematical calculations to solve problems related to everyday life. The process of mathematical connection of students who have a visual learning style in solving problems is shown in Figure 2. 


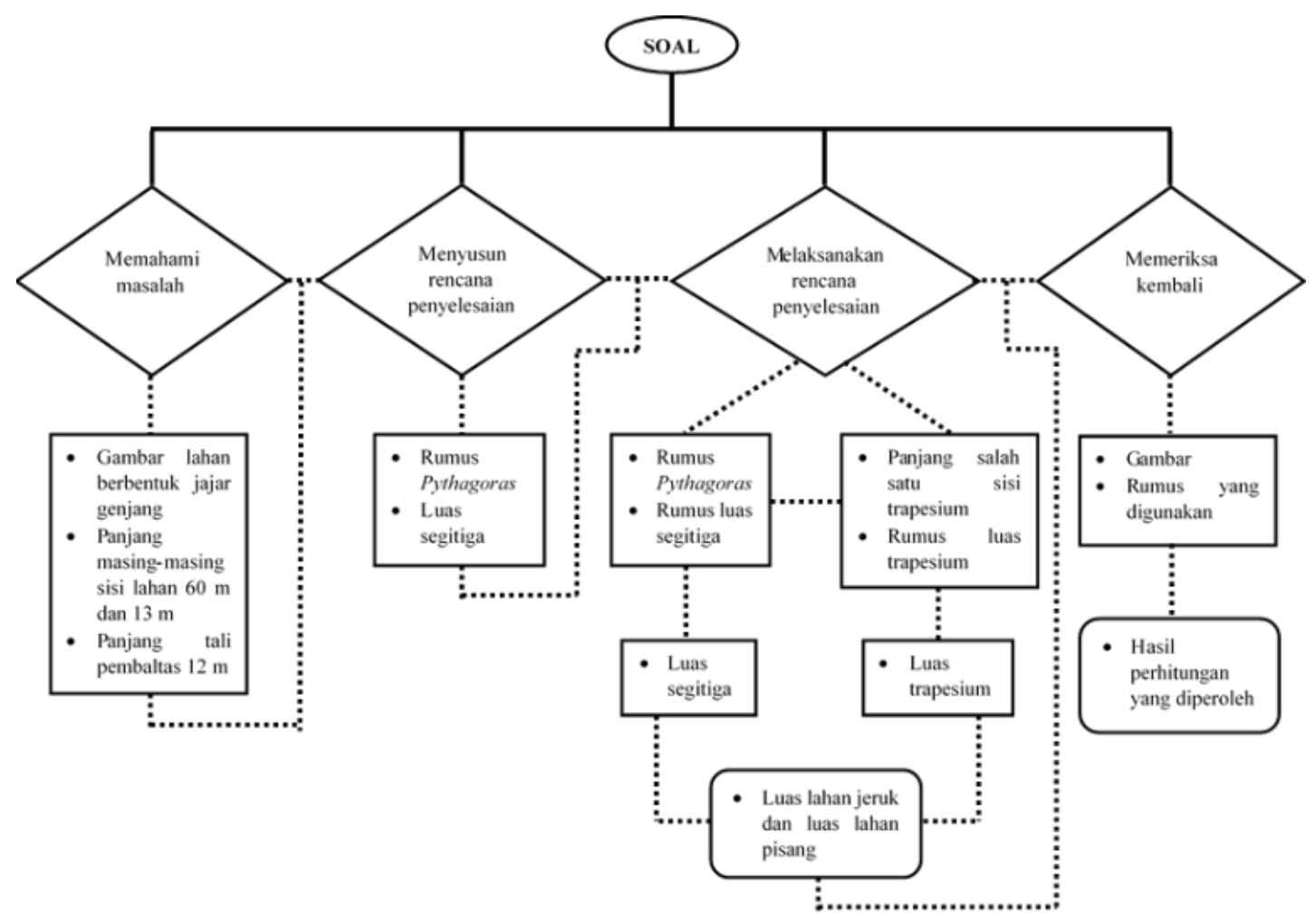

Figure 2. The mathematical connection process of students who have a visual learning style in solving problems

Remarks (also applies to Figure 4 and Figure 6):

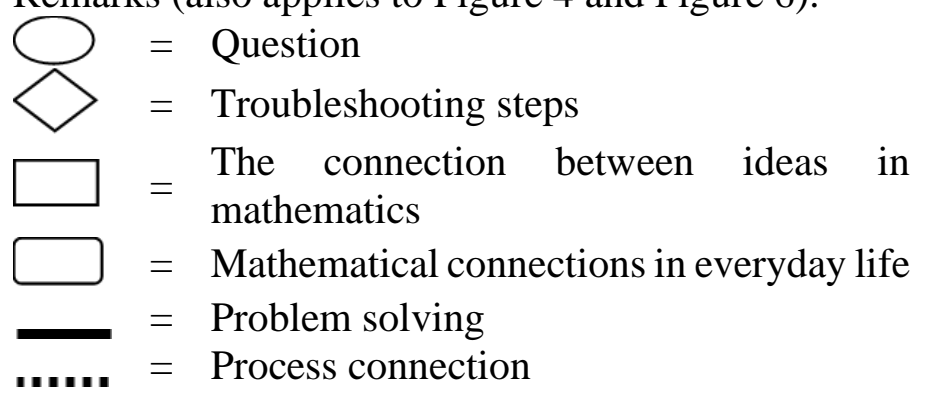

\subsection{The Process of Mathematical Connections of Students Who Have an Auditorial Learning Style in Solving Problems}

The process of mathematical connection of students in understanding the problem is only by presenting known information, namely the length of the base and the height of the triangle and parallelogram, as well as problems with the questions verbally, because of the difficulty in translating the questions in the form of pictures. The connections that students make in the step of understanding the problem lead to connections between ideas in mathematics. The results of the following interviews show that in understanding the problem, students provide known information, namely the length of the base and the height of the triangle and parallelogram as well as the problems in the questions.

$\mathrm{P}$ : What information do you know about the questions?

A : The information from the problem that I know is the length of the base of the triangle is $13 \mathrm{~m}$, the length of the base of the parallelogram is $60 \mathrm{~m}$, the height of the triangle and the height of the parallelogram is $12 \mathrm{~m}$. 
$\mathrm{P} \quad$ : Why don't you write down the information that is known and what is asked for in the questions?

A : Because I have a hard time, Mom, if you read long writing, let alone draw. I'm also not used to writing down what is known and what is being asked in the question ma'am.

$\mathrm{P}$ : Try to state what is asked from the question?

A : The area of land for oranges and land for bananas Bu.

The process of mathematical connection of students in preparing a settlement plan is by using the formula for the area of a triangle and the area of a parallelogram. The connections that students make in the step of developing a plan for completion lead to connections between ideas in mathematics. The process of mathematical connection of students in implementing the settlement plan is to calculate the area of land for bananas and land for oranges using the formula for the area of a triangle and the area of a parallelogram by substituting the base length and height. The connections that students make in the step of implementing the completion plan lead to connections between ideas in mathematics and mathematical connections in everyday life. The connection between ideas in mathematics can be seen from the use of relationships between facts, concepts, mathematical principles to create models or formulas needed to solve problems. The connection of mathematics in everyday life can be seen from the application of the relationship between concepts and procedures and operations of mathematical calculations to solve problems related to everyday life. In Figure 3, it can be seen that in implementing the completion plan, students first calculate the area of a right triangle using the area formula of a triangle, then calculate the area of a parallelogram using the parallelogram area formula. Students only substitute the length of the base of the triangle and parallelogram and its height to operate on the area formula for the triangle and the area formula for the parallelogram. It can be seen that in implementing the solution plan, the students first calculate the area of a right triangle using the area formula of the triangle, then calculate the area of a parallelogram using the parallelogram area formula. Students only substitute the length of the base of the triangle and parallelogram and its height to operate on the area formula for the triangle and the area formula for the parallelogram. It can be seen that in implementing the solution plan, the students first calculate the area of a right triangle using the area formula of the triangle, then calculate the area of a parallelogram using the parallelogram area formula. Students only substitute the length of the base of the triangle and parallelogram and its height to operate on the area formula for the triangle and the area formula for the parallelogram.

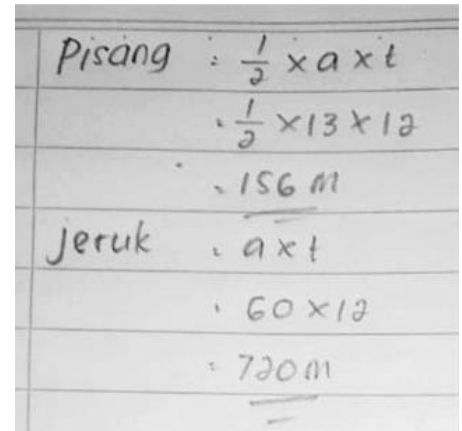

Figure 3. The mathematical connection process of students who have an auditory learning style in carrying out the completion plan

The process of mathematical connection of students in checking back does not occur 
because the student does not re-check the results obtained. The connections made by students who have an auditory learning style are only carried out in three steps of problem solving, namely understanding the problem, compiling a resolution plan, and carrying out the solution plan. The process of mathematical connection of students who have an auditory learning style in solving problems is shown in Figure 4.

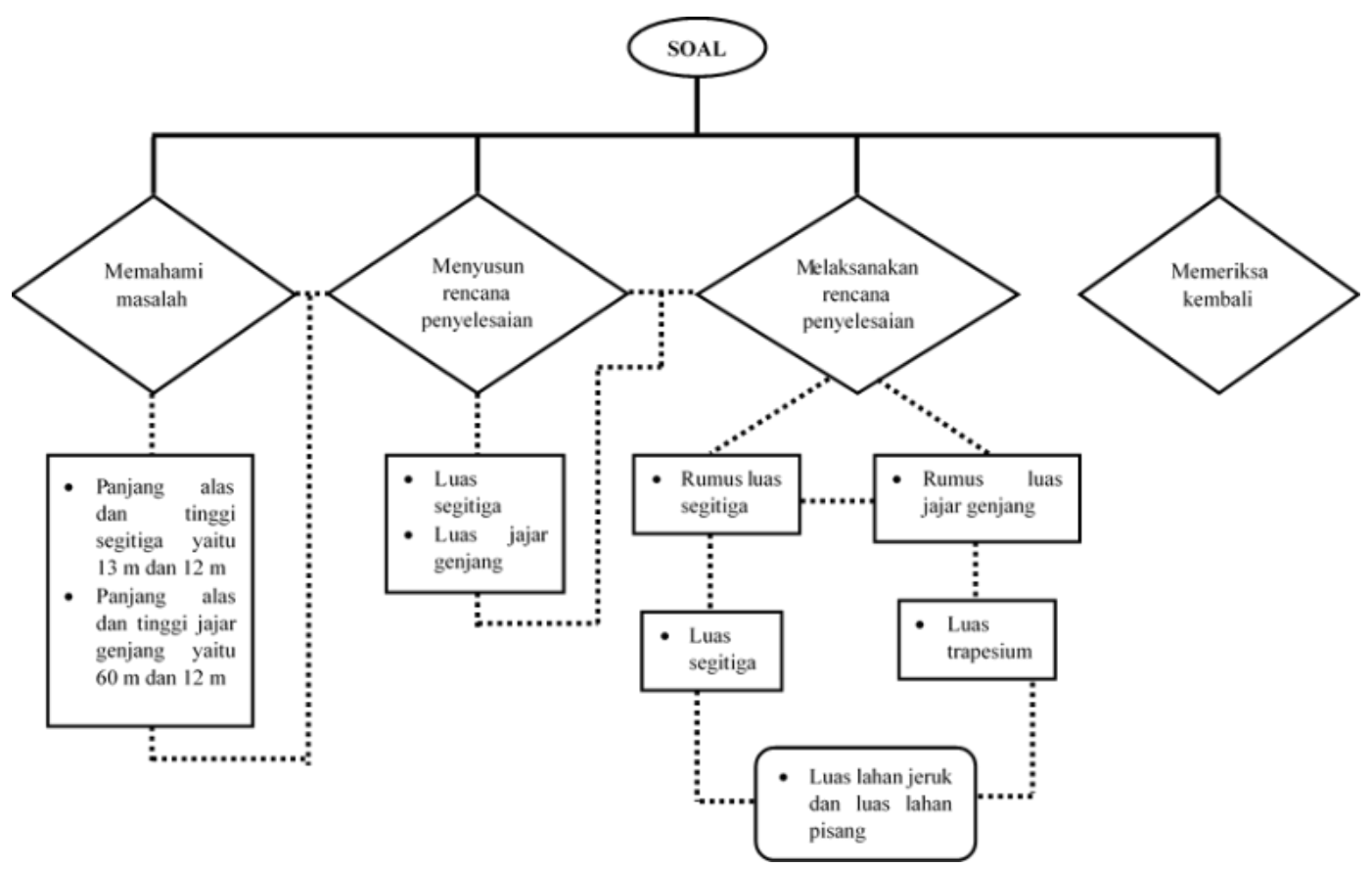

Figure 4. The mathematical connection process of students who have an auditory learning style in solving problems

\subsection{The Process of Mathematical Connections of Students Who Have Kinesthetic Learning Styles in Solving Problems}

The process of mathematical connection of students in understanding the problem is to write down the information that is known from the question in the form of a parallelogram image along with the information related to the problem in the question, namely the area of land for oranges and banana land. The connections that students make in the step of understanding the problem lead to connections between ideas in mathematics. In Figure 5, it can be seen that the students mentioned the information they knew by drawing Pak Ahmad's land, which was accompanied by the length of each side of the land, as well as the position of the bounding rope with its length.

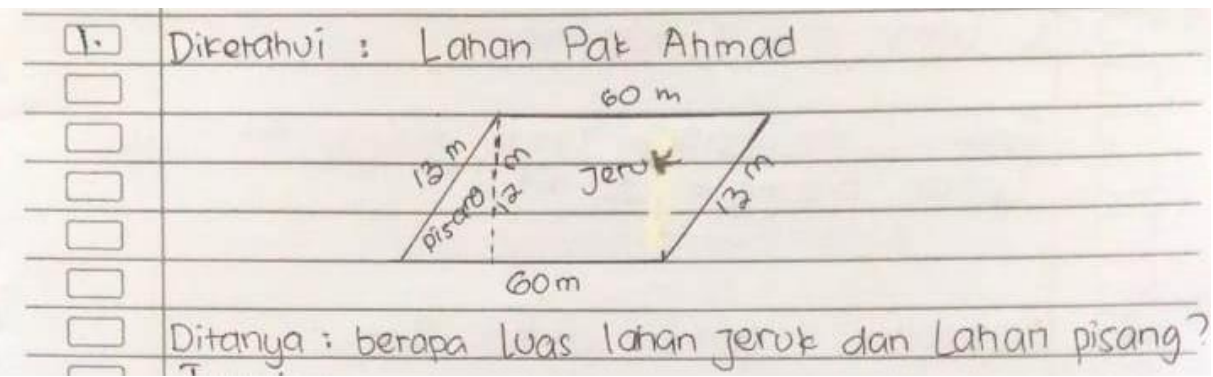

Figure 5. The process of mathematical connection of students who have a kinesthetic learning style in understanding the problem 
The following interview results also show that the students understood the problem by drawing Pak Ahmad's land, accompanied by the length of each side of the land, as well as drawing the position of the bounding rope with its length. Students also raise the problems that are asked in the questions.

$\mathrm{P}$ : Tell me how you understand the problem from the question?

$\mathrm{K}$ : I read while I wrote down what was known in the problem, then I drew a parallelogram with its height, then I wrote down the length of the parallelogram $60 \mathrm{~m}$ and the height $12 \mathrm{~m}$. I also wrote down the length of the hypotenuse of a right triangle, which is $13 \mathrm{~m}$. After I have written everything, then I write down what was asked in the question.

$\mathrm{P}$ : Try to state what is asked from the question?

$\mathrm{K}$ : Asking about the area of land for oranges and the area of banana land, Bu.

The process of mathematical connection of students in preparing a settlement plan is by using the Pythagorean formula to first find the length of the base of the right triangle. The connections that students make in the step of developing a plan for completion lead to connections between ideas in mathematics. The process of mathematical connection of students in implementing the settlement plan is by calculating the area of a right-angled trapezoid to find the area of land for oranges by subtracting the area of a parallelogram from the area of a right triangle. The connections that students make in the step of implementing the completion plan lead to connections between ideas in mathematics and mathematical connections in everyday life. The process of mathematical connection of students in rechecking, namely by checking the suitability between checking the answer results from the picture, formula used, and the calculation results obtained. The connections that students make in the reexamination step lead to connections between ideas in mathematics and mathematical connections in everyday life. The connection between ideas in mathematics can be seen from the use of relationships between facts, concepts, mathematical principles to create models or formulas needed to solve problems. The connection of mathematics in everyday life can be seen from the application of the relationship between concepts and procedures and operations of mathematical calculations to solve problems related to everyday life. The process of mathematical connection of students who have a kinesthetic learning style in solving problems is shown in Figure 6. The connections that students make in the reexamination step lead to connections between ideas in mathematics and mathematical connections in everyday life. The connection between ideas in mathematics can be seen from the use of relationships between facts, concepts, mathematical principles to create models or formulas needed to solve problems. The connection of mathematics in everyday life can be seen from the application of the relationship between concepts and procedures and operations of mathematical calculations to solve problems related to everyday life. The process of mathematical connection of students who have a kinesthetic learning style in solving problems is shown in Figure 6. The connections that students make in the reexamination step lead to connections between ideas in mathematics and mathematical connections in everyday life. The connection between ideas in mathematics can be seen from the use of relationships between facts, concepts, mathematical principles to create models or formulas needed to solve problems. The connection of mathematics in everyday life can be seen from the application of the relationship between concepts and procedures and operations of mathematical calculations to solve problems related to everyday life. The process of mathematical connection of students who have a kinesthetic learning style in solving problems is shown in Figure 6. mathematical principles to create the models or formulas needed to solve problems. The 
connection of mathematics in everyday life can be seen from the application of the relationship between concepts and procedures and operations of mathematical calculations to solve problems related to everyday life. The process of mathematical connection of students who have a kinesthetic learning style in solving problems is shown in Figure 6. mathematical principles to create the models or formulas needed to solve problems. The connection of mathematics in everyday life can be seen from the application of the relationship between concepts and procedures and operations of mathematical calculations to solve problems related to everyday life. The process of mathematical connection of students who have a kinesthetic learning style in solving problems is shown in Figure 6.

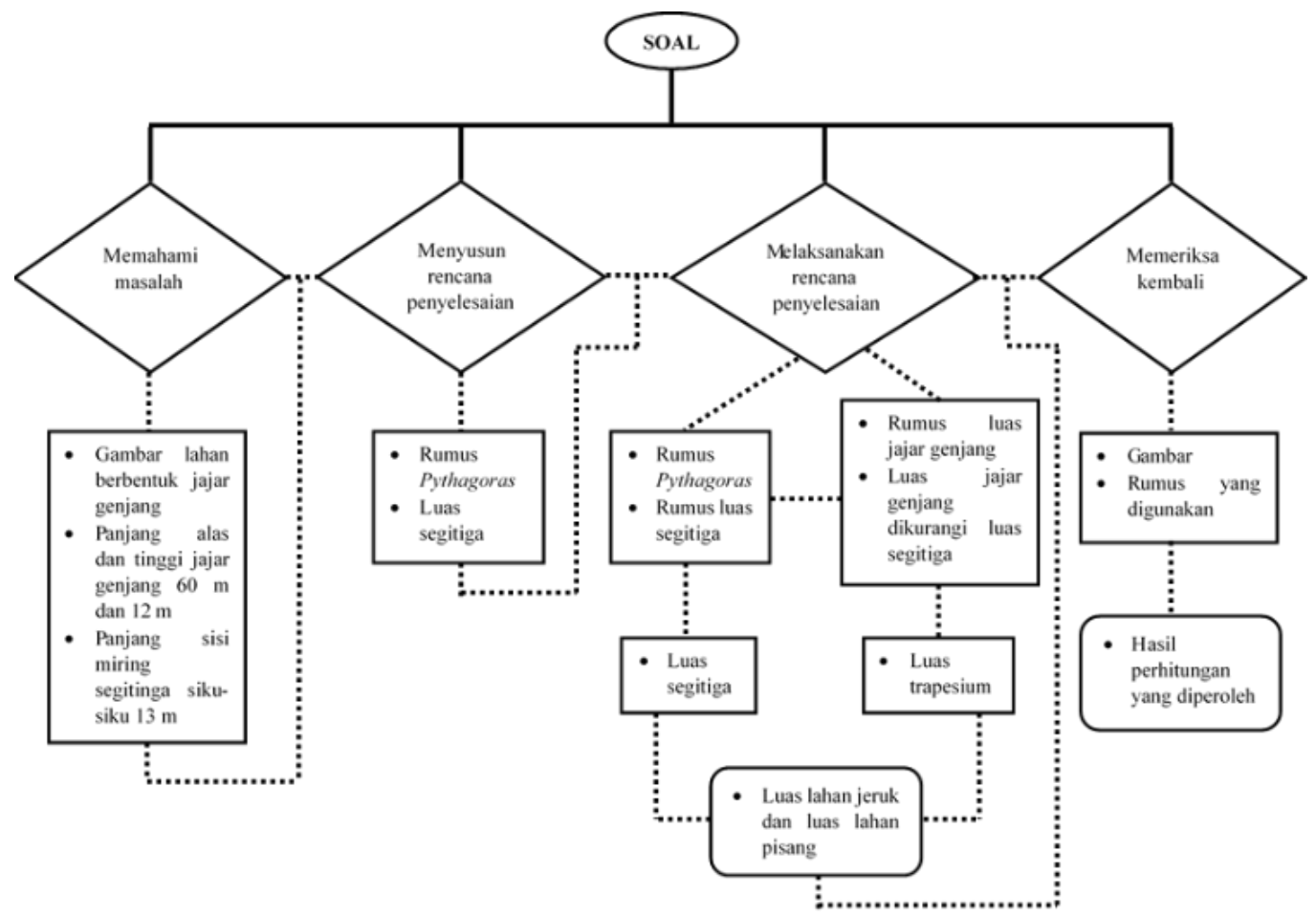

Figure 6. The mathematical connection process of students who have a kinesthetic learning style in solving problems

\section{Discussion}

The process of mathematical connection of students who have visual and kinesthetic learning styles in understanding the problem is to write down the information that is known from the question in the form of a parallelogram image along with its information relating to the problem in the area of land for oranges and banana land. The connection process of students who have an auditory learning style in understanding the problem is only by presenting known information, namely the length of the base and the height of the triangle and parallelogram, as well as problems with the questions verbally, because of the difficulty in translating the questions in the form of images. The connections made by students who have visual, auditory, and kinesthetic learning styles lead to connections between ideas in mathematics, namely identifying the relationship between facts, concepts, and mathematical principles on the problem to be solved. There are similarities in the mathematical connection process in understanding problems between students who have visual and kinesthetic learning styles, and there are differences in the mathematical connection process in understanding problems between students who have visual and kinesthetic learning styles and students who have auditory learning styles, which means that the individual way of thinking in the process of 
receiving, organizing and analyzing data from information that has been obtained through different perspectives, so that students have their own way of expressing mathematical concepts (Fauzi \& Priatna, 2019; Ghufron \& Risnawita, 2012).

The process of mathematical connection of students who have visual and kinesthetic learning styles in preparing the completion plan is by using the Pythagorean formula to find the base length of a right triangle first. The process of connecting students who have an auditory learning style in preparing a settlement plan is by using the formula for the area of a triangle and the area of a parallelogram. The connections made by students who have visual, auditory, and kinesthetic learning styles lead to connections between ideas in mathematics, namely using relationships between facts, concepts, mathematical principles to create models or formulas needed to solve problems. There is a similarity in the process of mathematical connections in preparing the completion plan between students who have visual and kinesthetic learning styles (Argarini, 2018; Richardo et al., 2014).

The connection process of students who have a visual learning style in carrying out the completion plan is by using the triangle area formula to calculate the area of the banana land and the trapezoid formula to calculate the area of land for oranges. The process of students who have a kinesthetic learning style in carrying out the completion plan is by calculating the area of a right-angled trapezoid to find the area of land for oranges by subtracting the area of a parallelogram from the area of a right triangle. The mathematical connection process of students who have an auditory learning style in carrying out the settlement plan is by calculating the area of banana and orange land using the formula for the area of a triangle and the area of a parallelogram by substituting the base length and height. The connections made by students who have a visual, auditorial, learning style and kinesthetic leads to connections between ideas in mathematics and mathematical connections in everyday life. The connection between ideas in mathematics is done by making a relationship between one concept and another in solving problems. Mathematical connections in everyday life are carried out by translating problems related to everyday life into the language of mathematics and applying the relation of concepts to mathematical arithmetic procedures and operations to solve problems related to everyday life. There are differences in the process of mathematical connections in implementing the completion plan between students who have visual, auditory, and kinesthetic learning styles (Budiarti \& Jabar, 2016; Diana et al., 2017; Sari et al., 2018).

The mathematical connection process of students who have visual and kinesthetic learning styles in checking again is by checking the suitability between checking the answer results from the picture, the formula used, and the calculation results obtained. The connections made by students who have visual learning styles and students who have kinesthetic learning styles lead to connections between ideas in mathematics and mathematical connections in everyday life. The connection between ideas in mathematics can be seen from the use of relationships between facts, concepts, mathematical principles to create models or formulas needed to solve problems. The connection of mathematics in everyday life can be seen from the application of the relationship between concepts and procedures and operations of mathematical calculations to solve problems related to everyday life. The process of connecting students who have an auditory learning style does not occur because these students do not re-check the results obtained, so that the connections made are also not visible. There is a similarity in the process of mathematical connections in re-examining completion between students who have visual and kinesthetic learning styles, and there are differences in the mathematical connection process in re-checking the completion between students who have visual and kinesthetic learning styles and students who have auditory learning styles, which means one's way. observe, process (Aini et al., 2016; Apipah \& Kartono, 2017; Warih, Parta, \& Rahardjo, 2016). 


\section{Conclusion}

From the description that has been explained, it is concluded that students who have a visual learning style and show their mathematical connection process in solving mathematical problems in the four steps of solving the problem, namely understanding the problem, compiling a plan for completion, and executing the solution plan, and re-checking the solution. The connections made by students who have visual and kinesthetic learning styles in solving problems lead to connections between ideas in mathematics and mathematical connections in everyday life. However, the mathematical connection process carried out by students who have visual and kinesthetic learning styles is different. Students who have an auditory learning style show their mathematical connection process in solving mathematical problems in only three steps of problem solving, namely understanding the problem, compiling a resolution plan, and implementing a settlement plan. The process of mathematical connection of students who have auditory learning styles in checking back does not occur, because these students do not recheck the results obtained. The connections made by students who have an auditory learning style in the three steps of solving these problems lead to connections between ideas in mathematics and mathematical connections in everyday life. Thus, the process of mathematical connection between students who have different visual, auditory, and kinesthetic learning styles in solving math problems. because the student does not re-check the results obtained. The connections made by students who have an auditory learning style in the three steps of solving these problems lead to connections between ideas in mathematics and mathematical connections in everyday life. Thus, the process of mathematical connection between students who have different visual, auditory, and kinesthetic learning styles in solving math problems. because the student does not re-check the results obtained. The connections made by students who have an auditory learning style in the three steps of solving these problems lead to connections between ideas in mathematics and mathematical connections in everyday life. Thus, the process of mathematical connection between students who have different visual, auditory, and kinesthetic learning styles in solving math problems.

\section{Suggestions}

The results showed that the learning style influenced the mathematical connection process carried out by students in solving math problems. Thus, the researcher suggests that teachers need to pay attention to the learning styles possessed by students and familiarize students to connect mathematics internally, namely connecting ideas in mathematics and externally, namely connecting mathematics in everyday life. This study is limited to only examining the process of mathematical connections in solving mathematical problems with a review of learning styles. Therefore, in the next research, the researcher expects the addition of other variables related to the mathematical connection process.

\section{References}

[1]. Aini, N. K., Purwanto, \& Sa'dijah, C. (2016). Mathematical Connection Process of High and Low Ability Students in Solving Flat-Building Problems. Jurnal Pendidikan, 1(3), 377-388.

[2]. Anggito, A., \& Setiawan, J. (2018). Qualitative Research Methodology. Sukabumi: CV. Jejak.

[3]. Anita, I. W. (2014). The Effect of Mathematics Anxiety on the Mathematical Connection Ability of Junior High School Students. Infinity Journal, 3(1), 125. https://doi.org/10.22460/infinity.v3i1.43

[4]. Apipah, S., \& Kartono. (2017). Analysis of Mathematical Connection Ability Based on Student Learning Styles in the VAK Learning Model with Abstract Self Assessment. UNNES Journal of Mathematics Education Research, 6(2), 148-156.

[5]. Apriyono, F. (2018). Profile of Junior High School Students' Mathematical Connection Ability in Solving Mathematics Problems in terms of Gender. Mosharafa: Jurnal Pendidikan Matematika, 5(2), 159-168. https://doi.org/10.31980/mosharafa.v5i2.271 
[6]. Argarini, D. F. (2018). Analysis of Polya-Based Problem Solving on Vector Multiplication Material in terms of Learning Styles. Matematika Dan Pembelajaran, 6(1), 91. https://doi.org/10.33477/mp.v6i1.448

[7]. Ariati, K. L., \& Hartati, L. (2017). Mathematical Problem Solving Ability in terms of Creativity and Emotional Intelligence. Jurnal Analisa, 3(2), 106-114. https://doi.org/10.15575/ja.v3i2.2011

[8]. Arikunto, S. (2014). Research Procedure: A Practice Approach. Jakarta: Rineka Cipta.

[9]. Baiduri, Putri, O. R. U., \& Alfani, I. (2020). Mathematical connection process of students with high mathematics ability in solving PISA problems. European Journal of Educational Research, 9(4), 15271537. https://doi.org/10.12973/EU-JER.9.4.1527

[10]. Budiarti, I., \& Jabar, A. (2016). The Influence of Learning Styles on Mathematics Learning Outcomes of Class VIII Students of SMPN 2 Banjarmasin in the 2015/2016 Academic Year. Math Didactic: Jurnal Pendidikan Matematika, 2(3), 142-147. https://doi.org/10.33654/math.v2i3.42

[11]. Denzin, N. K., \& Yvonna, S. L. (2009). Triangulation in Qualitative Research. Yogyakarta: Pustaka Belajar.

[12]. DePorter, B., \& Hernacki, M. (2013). Quantum Learning: Making Learning Comfortable and Fun. Bandung: Kaifa.

[13]. Diana, R. F., Irawan, E. B., \& Susiswo. (2017). The Process of Students' Mathematical Connection with Reflective Cognitive Style in Solving Algebraic Problems Based on SOLO Taxonomy. Jurnal Kajian Pembelajaran Matematika, 1(1), 52-63.

[14]. Dwirahayu, G., \& Firdausi. (2016). The Effect of Thinking Style on Students' Mathematical Connection Ability. Jurnal JPPM, 9(2), 210-221.

[15]. Fauzi, M. R., \& Priatna, N. (2019). Analysis of Student's Mathematical Connection and Communication in Algebra: The Exponential Equations. Journal of Physics: Conference Series, 1211(1), 0-5. https://doi.org/10.1088/1742-6596/1211/1/012065

[16]. Ghufron, M., \& Risnawita, R. (2012). Learning Style Theoretical Studies. Yogyakarta: Pustaka Belajar.

[17]. Hadi, S., \& Radiyatul, R. (2014). According to Polya's Problem Solving Method to Develop Students' Ability in Mathematical Problem Solving in Junior High School. EDU-MAT: Jurnal Pendidikan Matematika, 2(1), 53-61. https://doi.org/10.20527/edumat.v2i1.603

[18]. Hendriana, H., Slamet, R. U., \& Sumarmo, U. (2014). Mathematical Connection Ability and SelfConfidence (An Experiment on Junior High School Students through Contextual Teaching and Learning With Mathematical Manipulative). International Journal of Education, 8(1), 1-11. https://doi.org/10.17509/ije.v8i1.1726

[19]. Hidayah, I., Kurniaasih, D., \& Rohmad. (2019). An Analysis of Mathematical Connection Ability Viewed from Students ' Questioning -Skills through The Educational Tools in Connected Mathematics Project Learning Model. International Journal of Education, 8(1), 65-74. https://doi.org/10.15294/ujme.v8i1.25949

[20]. Hidayati, V. R., Subanji, S., \& Sisworo, S. (2020). Students' Mathematical Connection Error in Solving PISA Circle Problem. JIPM (Jurnal Ilmiah Pendidikan Matematika), 8(2), 76-84. https://doi.org/10.25273/jipm.v8i2.5588

[21]. Kenedi, A. K., Helsa, Y., Ariani, Y., Zainil, M., \& Hendri, S. (2019). Mathematical Connection of Elementary School Students to Solve Mathematical Problems. Journal on Mathematics Education, 10(1), 69-80.

[22]. Kogure, Y. (2013). PISA 2012 Assessment and Analytical Framework. Echinoderms: DurhamProceedings of the 12th International Echinoderm Conference, 621-626. https://doi.org/10.1201/9780203869543-c92

[23]. Latipah, E. D. P., \& Afriansyah, E. A. (2018). Analysis of Students' Mathematical Connection Ability Using CTL and RME Learning Approaches. Jurnal Matematika, 17(1), 1-12. https://doi.org/10.29313/jmtm.v17i1.3691

[24]. Lee, C. Y., \& Kung, H. Y. (2018). Math Self-Concept and Mathematics Achievement: Examining Gender Variation and Reciprocal Relations among Junior High School Students in Taiwan. Eurasia Journal of Mathematics, Science and Technology Education, 14(4), 1239-1252. https://doi.org/10.29333/ejmste/82535

[25]. Maftuh, M. S. (2018). Junior High School Student Creativity in Open Mathematical Problem Solving in terms of Learning Style. Buana Matematika: Jurnal Ilmiah Matematika Dan Pendidikan Matematika, 7(2), 75-84. https://doi.org/10.36456/buana_matematika.7.2:.1047.75-84

[26]. Mazana, M. Y., Montero, C. S., \& Casmir, R. O. (2018). Investigating Students' Attitude towards Learning Mathematics. International Electronic Journal of Mathematics Education, 14(1), 207-231. https://doi.org/10.29333/iejme/3997

[27]. Mhlolo, M. K. (2012). Mathematical Connections of A Higher Cognitive Level A Tool We May Use To Identify These in Practice. African Journal of Research in MST Education, 33(1), 49-64. 
https://doi.org/10.4102/pythagoras.v33i1.22

[28]. National Council of Teachers of Mathematics. (2000). Principles and Standards for School Mathematics. Journal of Equine Veterinary Science, 18(11), 719. https://doi.org/10.1016/s0737-0806(98)80482-6

[29]. Poladian, L., \& Zheng, C. (2016). Context, Connections and Communication: Using Journal Articles in Undergraduate Mathematics. International Journal of Innovation in Science and Mathematics Education, 24(5), 14-23.

[30]. Polya, G. (1973). How to Solve it. Princeton: Princeton University Press.

[31]. Puteh, M., \& Khalin, S. Z. (2016). Mathematics Anxiety and Its Relationship with the Achievement of Secondary Students in Malaysia. International Journal of Social Science and Humanity, 6(2), 119-122. https://doi.org/10.7763/ijssh.2016.v6.630

[32]. Richardo, R., Retno, D., \& Saputro, S. (2014). Student Creativity Levels in Solving Divergent Mathematical Problems in terms of Student Learning Styles (Studies in Class IX Students of Pelupuh State MTS, Sragen Regency Odd Semester, 2013/2014 Academic Year). Jurnal Elekronik Pembelajaran Matematika, 2(2), 144.

[33]. Rismawati, M., Irawan, E. B., \& Susanto, H. (2017). Mathematical Connection Structure of Class X Students on the Material of Two-Variable Linear Equation Systems. Jurnal Pendidikan : Teori, Penelitian, Dan Pengembangan, 2(4), 465-469.

[34]. Romli, M. (2016). Profile of Mathematical Connection of High School Female Students with High Mathematics Ability in Solving Mathematics Problems. Jurnal Ilmiah Pendidikan Matematika, 1(2), 145157. https://doi.org/10.26877/jipmat.v1i2.1241

[35]. Sari, F. K., Sudirman, \& Chandra, T. D. (2018). Junior High School Students' Mathematical Connection Process in Finishing Story Questions. Jurnal Pendidikan: Teori, Penelitian, Dan Pengembangan, 3(6), 715-722.

[36]. Siagian, M. D. (2016). Mathematical Connection Ability in Mathematics Learning. MES: Journal of Matematics Education and Science, 2(1), 58-67.

[37]. Sugiyono. (2015). Educational Research Methods (Quantitative, Qualitative, and R \& D Approaches). Bandung: Alfabeta.

[38]. Sundayana, R. (2016). The relationship between Learning Style, Independent Learning, and Problem Solving Ability of Junior High School students in Mathematics Lessons. Jurnal Pendidikan Matematika STKIP Garut, 5(2), 75-84.

[39]. Suparman, S. (2010). Teaching Style That Pleases Students. Yogyakarta: Pinus Book.

[40]. Tasni, N., \& Susanti, E. (2017). Building Students' Mathematical Connections in Verbal Problem Solving. Beta Jurnal Tadris Matematika, 10(1), 103. https://doi.org/10.20414/betajtm.v10i1.108

[41]. Warih, P. D., Parta, I. N., \& Rahardjo, S. (2016). Analysis of the Mathematical Connection Ability of Class VIII Students on the Pythagorean Theorem. Prosiding Konferensi Nasional Penelitian Matematika Dan Pembelajarannya [KNPMP I] Universitas Muhammadiyah Surakarta, 12 Maret 2016, 377-384.

[42]. Wiguna, S. A., Jatisunda, M. G., \& Santoso, E. (2019). Thinking Process of Students in Solving Problem Solving Problems Based on Auditory Learning Styles. Jurnal Didactical Mathematics, 1(2), 8-13.

[43]. Zulyanty, M., Yuwono, I., \& Muksar, M. (2017). Metacognition of Students with Introverted Learning Styles in Solving Mathematics Problems. Jurnal Kajian Pembelajaran Matematika, 1(1), 64-71. 